\title{
Analisis Hasil Perencanaan pada Pemodelan Stabilitas Timbunan dengan Program Bantu XSTABL, GEO5, GeoStudio-SLOPE/W, dan PLAXIS
}

\author{
Widya Indriyani Manurung ${ }^{1, *}$, Indrasurya B. Mochtar ${ }^{1}$, Trihanyndio Rendy Satrya ${ }^{1}$ \\ Departemen Teknik Sipil, Institut Teknologi Sepuluh Nopember ${ }^{1}$ \\ Koresponden*, Email: widyaindriyani.m@gmail.com
}

\begin{tabular}{lll}
\hline & Info Artikel & Abstract \\
\hline Diajukan & 26 Juni 2021 & The stability of the embankment in general can be calculated using the limit equilibrium \\
Diperbaiki & 22 Juli 2021 & method in the form of the XSTABL, GEO5, GeoStudio-SLOPE/W auxiliary programs and the \\
Disetujui & finite element method in the form of the PLAXIS auxiliary program. The main outputs of the \\
& auxiliary program are the safety factor (SF), moment resistance, and the location of the \\
& landslide area. However, the problem that always arises is that there are different outputs for \\
& the same input data in the four auxiliary programs. In this case, the planners still do not know \\
& which auxiliary program is appropriate to use in analyzing field conditions for planning. From \\
& the results of this study, obtained from the analysis of embankment stability for all variations \\
in height placed on subgrade with varying thickness of soft soil that has not undergone & compression (without installing PVD) carried out with XSTABL, GEO5, and GeoStudio- \\
Keywords: safety factor, GEO5, & SLOPE/W gives the same SF results; but PLAXIS is different. While the conditions that have \\
GeoStudio-SLOPE/W, PLAXIS, XSTABL & undergone compression (with PVD installed) carried out with XSTABL, GEO5 are the same; \\
& but GeoStudio-SLOPE/W and PLAXIS are different.
\end{tabular}

Abstrak

Stabilitas timbunan pada umumnya dapat dihitung dengan menggunakan metode keseimbangan batas berupa program bantu XSTABL, GEO5, GeoStudio-SLOPE/W dan metode elemen hingga berupa program bantu PLAXIS. Output utama dari program bantu tersebut adalah angka keamanan (SF), momen penahan, dan letak bidang longsor. Namun, masalah yang selalu timbul adalah adanya output yang berbeda untuk data input yang sama pada keempat program bantu tersebut. Dalam hal ini, para perencana masih belum mengetahui program bantu mana yang tepat untuk digunakan dalam menganalisis kondisi lapangan untuk perencanaan. Dari hasil penelitian ini, didapatkan dari analisis stabilitas timbunan untuk semua variasi ketinggian yang diletakkan di atas tanah dasar dengan ketebalan tanah lunak yang bervariasi yang belum mengalami pemampatan (tanpa dipasang PVD) yang dilakukan dengan XSTABL, GEO5, dan GeoStudio-SLOPE/W memberikan hasil SF yang sama; tetapi PLAXIS berbeda. Sedang kondisi yang telah mengalami pemampatan (dengan dipasang PVD) yang dilakukan dengan XSTABL, GEO5

Kata kunci: angka keamanan, GEO5, adalah sama; tetapi GeoStudio-SLOPE/W dan PLAXIS berbeda.

dapat digunakan metode keseimbangan batas (limit equili-

\section{Pendahuluan}

Tanah lunak merupakan tanah kohesif yang mempunyai sifat lekatan antar butir-butirnya dan memiliki kekuatan yang rendah. Jika tanah lunak digunakan sebagai dasar konstruksi maka dapat menimbulkan suatu permasalahan pada pembangunan, salah satunya pada jalan. Permasalahan yang sering ditemukan pada pembangunan jalan yaitu ketidakstabilan timbunan pada tanah lunak.

Ketidakstabilan suatu timbunan dapat menimbulkan kelongsoran dari timbunan akibat daya dukung tanah yang rendah. Selain itu timbunan juga akan mengalami pemampatan dari lapisan tanah dasar yang besar akibat peristiwa konsolidasi. Pemampatan konsolidasi adalah pengurangan volume tanah yang diakibatkan oleh keluarnya air pori dari dalam tanah. Untuk menganalisis stabilitas suatu timbunan brium method) yaitu program bantu XSTABL, GEO5, dan GeoStudio-SLOPE/W; di samping itu tersedia juga metode elemen hingga (finite element method) yang berupa program bantu PLAXIS. Perbedaan prinsip dari keempat program bantu tersebut adalah XSTABL, GEO5, dan GeoStudioSLOPE/W menghasilkan banyak bidang longsor beserta angka keamanannya, sedangkan PLAXIS hanya menghasilkan satu bidang longsor beserta angka keamanannya. Dengan demikian, PLAXIS tidak memberikan banyak alternatif bidang longsor untuk perencana.

Beberapa peneliti telah menggunakan keempat program bantu tersebut untuk menganalisis stabilitas suatu timbunan dimana data timbunan dan parameter tanah dasarnya sama tetapi menghasilkan output yang berbeda. Herman dan Liong 
dalam penelitiannya melakukan analisis stabilitas lereng timbunan di atas lempung lunak di Malaysia dengan menggunakan metode limit equilibrium berupa GeoStudioSLOPE/W 2007 dan metode finite element PLAXIS 2D versi 8.2 menghasilkan nilai faktor keamanan yang berbeda seperti yang ditunjukkan pada Tabel 1. Pada Tabel 2, diberikan hasil perhitungan dengan metode limit equilibrium dan metode finite element dimana terdapat perbedaan sebesar 3\% pada nilai faktor keamanannya [1].

Tabel 1. Rangkuman Hasil Faktor Keamanan [1]

\begin{tabular}{|c|c|c|}
\hline \multirow{2}{*}{$\begin{array}{c}\text { Metode } \\
\text { (Program Bantu) }\end{array}$} & \multirow[t]{2}{*}{ Metode Analisis } & $\begin{array}{c}\text { Faktor } \\
\text { Keamanan }\end{array}$ \\
\hline & & Proyek Malaysia \\
\hline \multirow{4}{*}{$\begin{array}{c}\text { Metode Finite } \\
\text { Element } \\
\text { (PLAXIS) }\end{array}$} & Plaxis A & $\leq 1$ (Runtuh) \\
\hline & Plaxis B & $\leq 1$ (Runtuh) \\
\hline & Plaxis C & $\leq 1$ (Runtuh) \\
\hline & Ordinary & 1.05 \\
\hline \multirow{5}{*}{$\begin{array}{l}\text { Metode Limit } \\
\text { Equilibrium } \\
\text { (GeoStudio- } \\
\text { SLOPE/W) }\end{array}$} & Bishop & 1.05 \\
\hline & Janbu & 0.93 \\
\hline & $\begin{array}{l}\text { Morgenstern- } \\
\text { Price }\end{array}$ & 0.975 \\
\hline & Spencer & 0.971 \\
\hline & Sarma & 0.963 \\
\hline
\end{tabular}

Tabel 2. Persentase Perbedaan Faktor Keamanan [1]

\begin{tabular}{|c|c|c|c|}
\hline \multirow[b]{2}{*}{ Proyek } & \multicolumn{2}{|c|}{ Metode } & \multirow{2}{*}{$\begin{array}{c}\% \\
\text { Perbedaan }\end{array}$} \\
\hline & $\begin{array}{c}\text { Limit } \\
\text { Equilibrium }\end{array}$ & $\begin{array}{c}\text { Finite } \\
\text { Element }\end{array}$ & \\
\hline $\begin{array}{l}\text { Timbunan } \\
\text { Malaysia }\end{array}$ & 0.99 & 0.96 & 3 \\
\hline
\end{tabular}

Selain itu, pola keruntuhan dari setiap metode yang dipakai juga memiliki perbedaan seperti yang ditunjukkan pada Gambar 1.

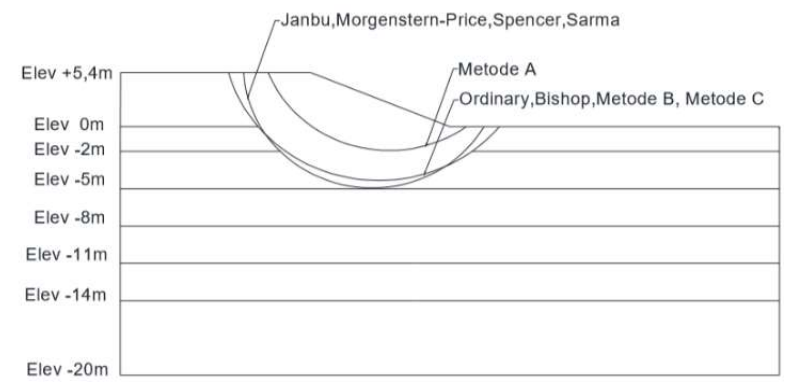

Gambar 1. Perbandingan pola keruntuhan proyek percobaan timbunan pada lempung lunak di Malaysia [1]
M. Sungkar dkk, dalam penelitiannya melakukan analisis stabilitas lereng di Jalan Nasional Meulaboh-Geumpang, Sungai Mas District, Kabupaten Aceh Barat, Provinsi Aceh dengan menggunakan metode Bishop yang mengasumsikan permukaan keruntuhan circular dan perhitungannya divalidasi dengan metode finite element berupa 2D PLAXIS versi 8.2 [2]. Hasil angka keamanan yang didapatkan adalah hampir sama antara 2 metode tersebut, seperti yang ditunjukkan pada Tabel 3.

Tabel 3. Perbedaan Faktor Keamanan [2]

\begin{tabular}{|c|c|c|}
\hline \multirow[b]{2}{*}{ Proyek } & \multicolumn{2}{|c|}{ Metode } \\
\hline & $\begin{array}{c}\text { Limit } \\
\text { Equilibrium }\end{array}$ & $\begin{array}{c}\text { Finite } \\
\text { Element }\end{array}$ \\
\hline $\begin{array}{c}\text { Jalan Nasional } \\
\text { Meulaboh-Geumpang, } \\
\text { Sungai Mas District }\end{array}$ & 1.080 & 1.100 \\
\hline
\end{tabular}

Desai, V. R. dan Joshi, M. R. dalam penelitiannya melakukan analisis stabilitas dengan menggunakan metode limit equilibrium berupa GeoSlope dan metode finite element berupa PLAXIS. Hasil angka keamanan yang diperoleh dengan me-nggunakan GeoSlope adalah 2.437 sedangkan program bantu PLAXIS menghasilkan nilai SF 2.420 untuk dry season [3].

Sulaiman, M. S. dkk dalam penelitiannya melakukan analisis stabilitas dengan menggunakan metode limit equilibrium berupa SLOPE/W dan metode finite element berupa PLAXIS. Hasil angka keamanan yang diperoleh dengan menggunakan SLOPE/W adalah 1.217 sedangkan program bantu PLAXIS menghasilkan nilai SF 1.060 [4].

Hasil angka keamanan yang dihasilkan oleh keempat program bantu tersebut dapat berbeda (tidak sama) dimana perbedaannya ada yang hampir sama ataupun sangat jauh. Masih belum diketahui penyebab terjadinya perbedaan output dari keempat program bantu tersebut sehingga masih belum ditemukan program bantu mana yang perlu dikoreksi untuk mendekati program bantu yang lebih tepat. Selain itu, perencana pun masih belum mengetahui program bantu mana yang tepat untuk digunakan dalam menggambarkan kondisi perencanaan di lapangan. Oleh karena itu, perlu dilakukan suatu penelitian untuk mengetahui letak perbedaannya sehingga didapatkan cara untuk menyamakan output (angka keamanan minimum) yang dihasilkan oleh program bantu XSTABL, GEO5, GeoStudio-SLOPE/W, dan PLAXIS.

\section{Metode}

Pengumpulan Data Sekunder 
Data tanah yang digunakan adalah data sekunder yang merujuk dari Tesis Septiandri R. A. dkk [5] dengan menggunakan rumus empiris Ardana dan Mochtar [6] untuk mencari nilai $\mathrm{c}_{\mathrm{u}}$ dan Kosasih dan Mochtar [7] untuk nilai $\mathrm{c}_{\mathrm{c}}$. Jenis tanah dasar yang digunakan hanya tanah lunak dengan konsistensi very soft, soft, dan medium.

\section{Review Data Tanah}

Review data tanah untuk menentukan jenis dan parameter tanah yang didapatkan sehingga dapat menentukan data tanah pakai untuk pengerjaan atau perhitungan penelitian. Parameter tanah yang akan dimasukkan ke dalam program bantu, rinciannya sebagai berikut:

- Program bantu XSTABL = gamma ( $\mathrm{\gamma})$, kohesi undrained $\left(c_{u}\right)$, kohesi efektif (c'), sudut geser dalam $(\varnothing)$.

- Program bantu GEO5 = gamma ( $\mathrm{\gamma})$, kohesi undrained $\left(c_{u}\right)$, kohesi efektif (c'), sudut geser dalam $(\varnothing)$.

- Program bantu GeoStudio-SLOPE/W = gamma ( $\mathrm{\gamma}$ ), kohesi undrained $\left(\mathrm{c}_{\mathrm{u}}\right)$, kohesi efektif (c'), sudut geser dalam (Ø).

- $\quad$ Program bantu PLAXIS = gamma (y), kohesi undrained $\left(c_{u}\right)$, kohesi efektif (c'), sudut geser dalam $(\varnothing)$, poisson ratio $(\mu)$, modulus Young $(\mathrm{E})$.

Data tanah nilai $\mathrm{c}_{\mathrm{u}}$ pakai pada tanah dasar yang belum mengalami pemampatan (lapisan tanah dasar tanpa dipasang PVD) menggunakan nilai $c_{u}$ tetap atau tanah asli belum terkonsolidasi sedangkan tanah dasar yang telah mengalami pemampatan (lapisan tanah dasar dengan dipasang PVD), nilai $\mathrm{c}_{\mathrm{u}}$ pakai akan dibedakan antara menggunakan nilai $\mathrm{c}_{\mathrm{u}}$ tetap atau tanah asli belum terkonsolidasi, $\mathrm{c}_{\mathrm{u}}$ peralihan atau setengah terkonsolidasi, dan $\mathrm{c}_{\mathrm{u}}$ meningkat atau bagian terkonsolidasi [6].

\section{Pemodelan Stabilitas Timbunan}

Pemodelan stabilitas timbunan direncanakan dengan memvariasikan tinggi timbunan dan ketebalan tanah lunak dimana variasi yang digunakan sebagai berikut:

- Tinggi timbunan $=4 \mathrm{~m}, 6 \mathrm{~m}, 8 \mathrm{~m}$, dan $10 \mathrm{~m}$.

- Ketebalan tanah lunak $=10 \mathrm{~m}, 15 \mathrm{~m}$, dan $20 \mathrm{~m}$.

Timbunan yang digunakan adalah timbunan urugan pilihan dengan spesifikasi lebar puncak $30 \mathrm{~m}$ dan kemiringan 1:2. Pada penelitian ini memiliki 2 kondisi yaitu tanah dasar yang belum mengalami pemampatan atau kondisi inisial (lapisan tanah dasar tanpa dipasang PVD) dan tanah dasar yang telah mengalami pemampatan (lapisan tanah dasar dengan dipasang PVD). Pemasangan PVD bertujuan untuk mempercepat proses pemampatan konsolidasi. Dalam melakukan analisis stabilitas timbunan menggunakan program bantu XSTABL, GEO5, GeoStudio-SLOPE/W, dan PLAXIS, tentunya harus memasukkan parameter yang sama ke dalam keempat program bantu tersebut, berupa parameter tanah, tinggi timbunan, dan ketebalan tanah lunak.

\section{Mencari Nilai SF Minimum yang Sama}

Setelah menganalisis stabilitas timbunan menggunakan keempat program bantu tersebut, akan didapatkan output berupa nilai SF minimum. Jika keempat program bantu tersebut menghasilkan nilai SF minimum yang berbeda maka perlu dilihat perbedaannya pada bidang kelongsoran dan momen penahan juga. Setelah itu, diteliti apa yang menyebabkan dari perbedaan output tersebut. Jika sudah mengetahui penyebabnya maka perlu mencari cara untuk menyamakan hasil analisis stabilitas timbunan dengan menggunakan keempat program bantu tersebut. Setelah mendapatkan caranya, perlu meng-running ulang program bantu sampai menghasilkan nilai SF minimum yang hampir sama dimana nilai angka keamanan yang dihasilkan dari program bantu XSTABL dijadikan sebagai acuan pada penelitian ini.

\section{Hasil dan Pembahasan \\ Data Tanah Pakai}

Pada penelitian ini menggunakan asumsi ketebalan tanah lunak maksimum adalah 20 meter. Data tanah untuk variasi ketebalan tanah lunak 10 meter diambil berdasarkan data tanah 10 meter dari permukaan, begitu pula untuk variasi ketebalan tanah lunak $15 \mathrm{~m}$ yang diambil berdasarkan data tanah $15 \mathrm{~m}$ dari permukaan [5]. Data tanah pakai untuk ket-ebalan tanah lunak $20 \mathrm{~m}$ dapat dilihat pada Tabel 4.

\section{Perhitungan Pemampatan}

Pada penelitian ini menggunakan 2 kondisi yaitu tanah dasar yang belum mengalami pemampatan atau kondisi inisial (lapisan tanah dasar tanpa dipasang PVD) dan tanah dasar yang telah mengalami pemampatan (lapisan tanah dasar dengan dipasang PVD) yang memiliki variasi tinggi timbunan 4-10 m. Untuk lapisan tanah dasar dengan dipasang PVD, variasi tinggi timbunan $4-10$ m dinyatakan sebagai $\mathrm{H}_{\text {akhir }}$ timbunan, karena timbunan tersebut sudah memampat $90 \%$ dalam kurun waktu 6 bulan. Maka perlu menghitung besar pemampatan yang telah terjadi menggunakan $\mathrm{H}_{\mathrm{awal}}$ timbunan.

Grafik hubungan antara $\mathrm{H}_{\text {akhir }}$ dengan $\mathrm{H}_{\text {awal }}$ dapat dilihat pada Gambar 2. Nilai $\mathrm{H}_{\text {awal }}$ timbunan didapatkan melalui per-samaan yang dihasilkan dari grafik antara $\mathrm{H}_{\text {akhir }}$ dengan $\mathrm{H}_{\text {awal }}$ timbunan dengan masing-masing ketebalan tanah lunak. Hasil rekapitulasi $\mathrm{H}_{\text {akhir }}$ dengan $\mathrm{H}_{\text {awal }}$ timbunan untuk kondisi dengan dipasang PVD, dapat dilihat pada Tabel 5. 


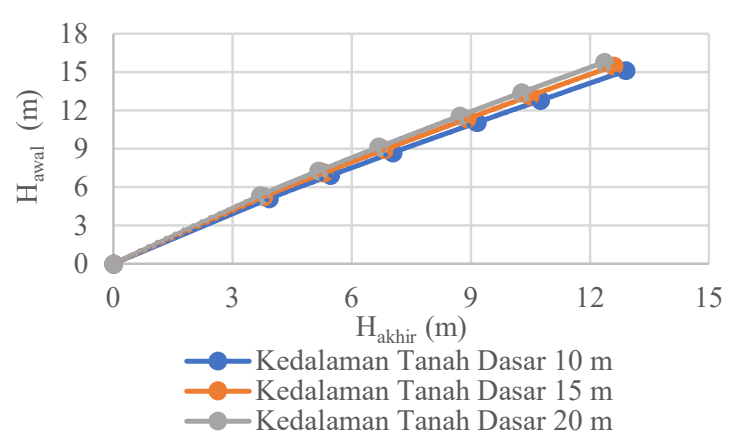

Gambar 2. Hubungan antara $\mathrm{H}_{\mathrm{akhir}}$ dengan $\mathrm{H}_{\text {awal }}$ timbunan

Tabel 5. Nilai $\mathrm{H}_{\mathrm{akhir}}$ dan $\mathrm{H}_{\text {awal }}$ Timbunan

\begin{tabular}{cccccc}
\hline \multicolumn{4}{c}{ Ketebalan Tanah Lunak } \\
\hline \multicolumn{2}{c}{$10 \mathrm{~m}$} & \multicolumn{2}{c}{$15 \mathrm{~m}$} & \multicolumn{2}{c}{$20 \mathrm{~m}$} \\
\hline $\mathrm{H}_{\text {akhir }}$ & $\mathrm{H}_{\text {awal }}$ & $\mathrm{H}_{\text {akhir }}$ & $\mathrm{H}_{\text {awal }}$ & $\mathrm{H}_{\text {akhir }}$ & $\mathrm{H}_{\text {awal }}$ \\
$\mathrm{m}$ & $\mathrm{m}$ & $\mathrm{m}$ & $\mathrm{m}$ & $\mathrm{m}$ & $\mathrm{m}$ \\
\hline 4 & 5.19 & 4 & 5.51 & 4 & 5.78 \\
6 & 7.54 & 6 & 7.97 & 6 & 8.38 \\
8 & 9.79 & 8 & 10.29 & 8 & 10.84 \\
10 & 11.98 & 10 & 12.53 & 10 & 13.24 \\
\hline
\end{tabular}

Perhitungan pemampatan menggunakan persamaan 1 dan $2[8]$.

jika $\Delta \sigma+\sigma_{\mathrm{o}}^{\prime}>\sigma_{\mathrm{p}}^{\prime}$

$\mathrm{Sc}=\frac{\mathrm{Cs \times \textrm {H } _ { \mathrm { o } }}}{1+\mathrm{e}_{\mathrm{o}}} \log \frac{{\sigma_{\mathrm{p}}^{\prime}}_{\sigma_{\mathrm{o}}}}{\sigma^{\prime}}+\frac{\mathrm{Ccx \textrm {H } _ { \mathrm { o } }}}{1+\mathrm{e}_{\mathrm{o}}} \log \frac{{\sigma^{\prime}}_{{ }_{\mathrm{o}}+\Delta \sigma}}{\sigma_{\mathrm{o}_{\mathrm{o}}}}$

jika, $\Delta \sigma+\sigma_{\mathrm{o}}^{\prime} \leq \sigma_{\mathrm{p}}^{\prime}$

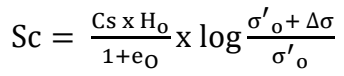

Untuk kondisi dengan dipasang PVD menggunakan parameter tanah $\mathrm{c}_{\mathrm{u}}$ yang dibedakan antara $\mathrm{c}_{\mathrm{u}}$ asli $\left(\mathrm{c}_{\mathrm{u}}\right.$ tanah asli belum terkonsolidasi), $c_{u}$ peralihan $\left(c_{u}\right.$ setengah terkonsolidasi), dan $c_{u}$ baru ( $c_{u}$ sudah terkonsolidasi) sesuai rumus Ardana dan Mochtar pada persamaan 3-4 [6].

$\mathrm{c}_{\mathrm{u}}$ asli $=0,0737+(0,1899-0,0016 \mathrm{PI}) \times \sigma^{\prime} \mathrm{p}$

$\mathrm{c}_{\mathrm{u}}$ baru $=0,0737+(0,1899-0,0016 \mathrm{PI}) \times\left(\Delta \sigma+\sigma^{\prime} \mathrm{o}\right)$

$\mathrm{c}_{\mathrm{u}}$ peralihan $=\frac{\mathrm{c}_{\mathrm{u}} \text { asli }+\mathrm{c}_{\mathrm{u}} \text { baru }}{2}$

\section{Analisis Stabilitas Timbunan dengan Program Bantu XSTABL}

Dalam melakukan analisis stabilitas timbunan dapat menggunakan program bantu XSTABL. Prinsip kerja program bantu XSTABL dalam mencari nilai angka keamanan dengan metode irisan atau pias-pias dengan pendekatan bidang kelongsoran berbentuk circular. Hasil output dari program bantu XSTABL berupa nilai SF minimum, bidang kelongsoran, dan moment resistance. Pada penelitian ini menggunakan 2 kondisi yaitu tanah dasar yang belum mengalami pemampatan (lapisan tanah dasar tanpa dipasang PVD) dan tanah dasar yang telah mengalami pemampatan (lapisan tanah dasar dengan dipasang PVD) dengan variasi ketinggian dan ketebalan tanah lunak. Untuk pemasangan kedalaman PVD sedalam tinggi timbunan.

Spesifikasi timbunan yang akan dianalisis dengan variasi ketinggian 4-10 m yang memiliki kemiringan 1:2 dan lebar puncak sebesar $30 \mathrm{~m}$ (lebar jalan tol). Timbunan berdiri di atas tanah lunak sedalam 10-20 m dimana seluruh lapisan tanah lunak ini termasuk dalam konsistensi very soft, soft, dan medium. Muka air tanah terletak pada permukaan dasar timbunan. Timbunan direncanakan sesuai dengan kondisi di lapangan dimana terdapat beban lalu lintas di puncak timbunan sebesar $10 \mathrm{kPa}$ [9]. Di pinggir timbunan terdapat bahu jalan sebesar 2,5 $\mathrm{m}$ dan di tengah timbunan terdapat median jalan sebesar $1 \mathrm{~m}$.

Dalam menganalisis stabilitas timbunan menggunakan program bantu XSTABL, dengan cara memvariasikan nilai initiation-termination. Pada penelitian ini, melakukan iterasi sebanyak 5 kali terhadap initiation-termination dari XSTABL. Untuk setiap 1 iterasi initiation-termination, akan ditentukan 10 SF minimum kritis oleh program bantu XSTABL dan dipilih SF terkecil dan R terdalam dari $10 \mathrm{SF}$ minimum tersebut. Metode analisis yang digunakan pada program bantu XSTABL adalah metode Bishop.

Contoh pemodelan untuk kondisi tanpa dan dengan dipasang PVD dengan tinggi timbunan $10 \mathrm{~m}$ dan ketebalan tanah lunak 20 m dapat dilihat pada Gambar 3 dan Gambar 4.

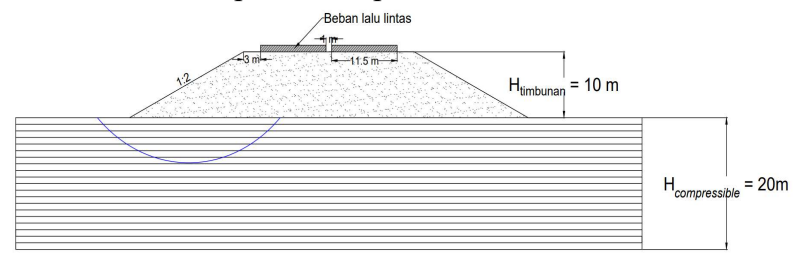

Gambar 3. Pemodelan pada program bantu XSTABL untuk kondisi tanpa dipasang PVD yang digambar dengan autocad

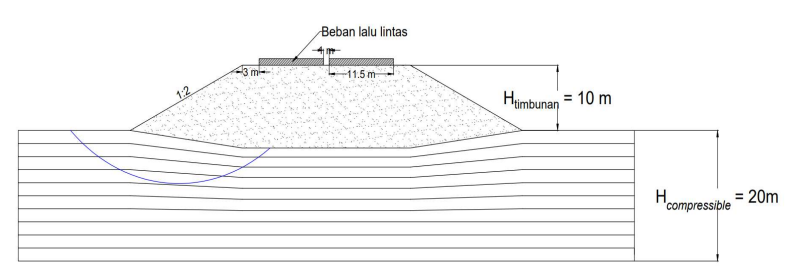

Gambar 4. Pemodelan pada program bantu XSTABL untuk kondisi dengan dipasang PVD yang digambar dengan autocad 
Analisis Stabilitas Timbunan dengan Program Bantu GEO5

Dalam menganalisis stabilitas timbunan atau melakukan pengecekkan overall stability suatu timbunan dapat menggunakan program bantu GEO5. Prinsip kerja program bantu GEO5 dalam mencari nilai angka keamanan dengan metode irisan atau pias-pias dengan pendekatan bidang kelongsoran berbentuk circular, sama seperti program bantu XSTABL. Hasil output dari program bantu GEO5 berupa nilai SF minimum, bidang kelongsoran, dan moment resistance.

Ketentuan pemodelan timbunan yang digambar pada program bantu GEO5, sama seperti program bantu XSTABL. Hal ini bertujuan untuk melihat hasil angka keamanan (SF) dari suatu timbunan dengan pemodelannya dan memasukkan parameter tanah yang sama jika dihitung menggunakan program bantu berbeda.

Dalam menganalisis stabilitas timbunan menggunakan program bantu GEO5 dengan tipe analisis optimization terlebih dahulu. Hal tersebut dilakukan untuk mencari nilai SF minimum. Selanjutnya, dilakukan analisis kembali; tipe analisis standard dengan cara mengubah bidang longsor mencapai kaki timbunan hingga menyentuh lapisan tanah dasar. Langkah tersebut dilakukan berulang kali hingga ditemukan pola nilai SF dan moment resistance yang dihasil-kan. Pada penelitian ini, melakukan iterasi sebanyak 5 kali terhadap tipe analisis optimization dan standard. Setiap 1 iterasi dengan tipe analisis secara optimization dan standard, dihasilkan masing-masing 1 SF minimum. Metode analisis yang digunakan pada program bantu GEO5 adalah metode Bishop.

Dalam menganalisis stabilitas menggunakan program bantu GEO5 untuk kondisi lapisan tanah dasar telah mengalami pemampatan (dengan dipasang PVD) dengan tinggi timbunan $10 \mathrm{~m}$ dan ketebalan tanah lunak $15 \mathrm{~m}$; tipe analisis optimization, didapatkan nilai SF minimum dan moment resistance membesar. Hal tersebut, karena adanya pening-katan parameter tanah $\mathrm{c}_{\mathrm{u}}$. Tetapi bidang longsor yang dihasilkan malah lebih dalam daripada kondisi inisial (lapisan tanah dasar tanpa dipasang PVD) sehingga hal ini tidak reliable. Hasil tersebut didapatkan dengan memodelkan geometri lapisan tanah dasar yang menurun. Maka dari itu perlu dicoba dengan memodelkan geometri lapisan tanah dasar yang lurus. Setelah dilakukan analisis, didapatkan hasil bidang longsor pada geometri lapisan tanah dasar yang lurus serupa dengan geometri lapisan tanah dasar yang menurun. Dapat disimpulkan bahwa pemodelan geometri lapisan tanah dasar yang menurun untuk kondisi dengan dipasang PVD, bukan penyebab didapatkannya hasil bidang longsor yang lebih dalam daripada kondisi tanpa dipasang PVD. Oleh karena itu, dalam mencari nilai SF minimum untuk kondisi dengan dipasang PVD; tipe analisis standard, dilakukan dengan cara mema- sukkan koordinat bidang longsor dari out-put analisis optimization kondisi tanpa dipasang PVD untuk semua variasi ketinggian dan ketebalan tanah lunak.

Contoh pemodelan untuk kondisi tanpa dan dengan dipasang PVD dengan tinggi timbunan $10 \mathrm{~m}$ dan ketebalan tanah lunak 20 m dapat dilihat pada Gambar 5 dan Gambar 6.

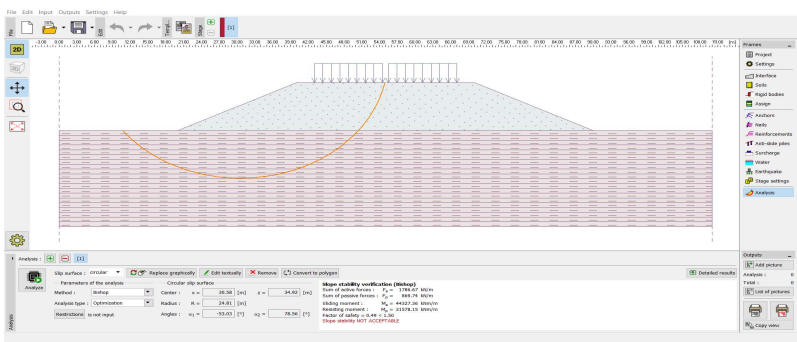

Gambar 5. Pemodelan pada program bantu GEO5 untuk kondisi tanpa dipasang PVD

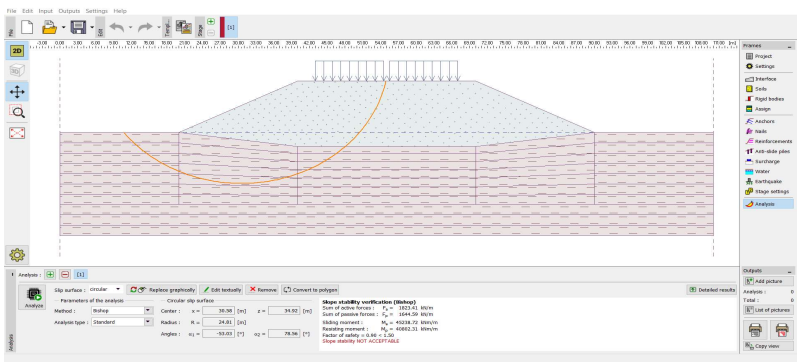

Gambar 6. Pemodelan pada program bantu GEO5 untuk kondisi dengan dipasang PVD

\section{Analisis Stabilitas Timbunan dengan Program Bantu GeoStudio-SLOPE/W}

Dalam menganalisis stabilitas timbunan atau melakukan pengecekkan overall stability suatu timbunan dapat menggunakan program bantu GeoStudio-SLOPE/W. Prinsip kerja program bantu GeoStudio-SLOPE/W dalam mencari nilai angka keamanan dengan metode irisan atau pias-pias dengan pendekatan bidang kelongsoran berbentuk circular, sama seperti program bantu XSTABL dan GEO5. Hasil output dari program bantu GeoStudio-SLOPE/W berupa nilai SF minimum, bidang kelongsoran, dan moment resistance.

Ketentuan pemodelan timbunan yang digambar pada program bantu GeoStudio-SLOPE/W, sama seperti program bantu XSTABL. Hal ini bertujuan untuk melihat hasil angka keamanan (SF) dari suatu timbunan dengan pemodelannya dan memasukkan parameter tanah yang sama jika dihitung menggunakan program bantu berbeda.

Dalam menganalisis stabilitas timbunan menggunakan program bantu GeoStudio-SLOPE/W, dengan cara memvariasikan nilai entry and exit slip surface. Pada penelitian 
ini, melakukan iterasi sebanyak 5 kali terhadap entry dan exit slip surface dari GeoStudio-SLOPE/W. Untuk setiap 1 iterasi entry dan exit slip surface, akan ditentukan $1 \mathrm{SF}$ minimum kritis oleh program bantu GeoStudio-SLOPE/W. Metode analisis yang digunakan pada program bantu GeoStudioSLOPE/W adalah metode Bishop.

Dalam menganalisis stabilitas menggunakan program bantu GeoStudio-SLOPE/W untuk kondisi lapisan tanah dasar telah mengalami pemampatan (dengan dipasang PVD) dengan tinggi timbunan $6 \mathrm{~m}$ dan ketebalan tanah lunak $20 \mathrm{~m}$ dari iterasi ke-1, didapatkan nilai SF minimum dan moment resistance membesar. Hal tersebut, karena adanya peningkatan parameter tanah $\mathrm{c}_{\mathrm{u}}$. Tetapi bidang longsor yang dihasilkan malah lebih dalam daripada kondisi inisial (lapisan tanah dasar tanpa dipasang PVD) sehingga hal ini tidak reliable. Hasil tersebut didapatkan dengan memodelkan geometri lapisan tanah dasar yang menurun. Maka dari itu perlu dicoba dengan memodelkan geometri lapisan tanah dasar yang lurus. Setelah dilakukan analisis, didapatkan hasil bidang longsor pada geometri lapisan tanah dasar yang lurus serupa dengan geometri lapisan tanah dasar yang menurun. Dapat disimpulkan bahwa pemodelan geometri lapisan tanah dasar yang menurun untuk kondisi dengan dipasang PVD, bukan penyebab didapatkannya hasil bidang longsor yang lebih dalam daripada kondisi tanpa dipasang PVD. Oleh karena itu, dalam mencari nilai SF minimum untuk kondisi dengan dipasang PVD; grid and radius slip surface, dilakukan dengan cara memasukkan koordinat bidang longsor dari output analisis entry and exit slip surface kondisi tanpa dipasang PVD untuk semua variasi ketinggian dan ketebalan tanah lunak.

Contoh pemodelan untuk kondisi tanpa dan dengan dipasang PVD dengan tinggi timbunan $10 \mathrm{~m}$ dan ketebalan tanah lunak 20 m dapat dilihat pada Gambar 7 dan Gambar 8.

\section{Analisis Stabilitas Timbunan dengan Program Bantu PLAXIS}

Dalam menganalisis stabilitas timbunan atau melakukan pengecekkan overall stability suatu timbunan dapat menggunakan program bantu PLAXIS. Prinsip kerja program bantu PLAXIS dalam mencari nilai angka keamanan dengan $\mathrm{phi} / \mathrm{c}$ reduction. Cara kerja phi/c reduction artinya dengan mereduksi nilai c dan tan $\phi$ hingga kelong-soran terjadi sehingga perhitungannya berbeda dengan pro-gram bantu XSTABL, GEO5, dan GeoStudio-SLOPE/W. Hasil output dari program bantu PLAXIS berupa nilai SF minimum dan displacement. Output gambar yang ditampil-kan hanya berupa bidang longsor tanpa titik koordinat bidang longsor dan moment resistance.
Ketentuan pemodelan timbunan yang digambar pada program bantu PLAXIS, sama seperti program bantu XSTABL. Hal ini bertujuan untuk melihat hasil angka keamanan (SF) dari suatu timbunan dengan pemodelannya dan memasukkan parameter tanah yang sama jika dihitung menggunakan program bantu berbeda.

Program bantu PLAXIS termasuk metode elemen hingga sehingga kalkulasi program tersebut berbeda dengan XSTABL, GEO5, dan GeoStudio-SLOPE/W yang termasuk dalam metode keseimbangan batas. Metode analisis pada pro-gram bantu PLAXIS mengharuskan perencana memodelkan perkerasan jalan setebal $20 \mathrm{~cm}$ dan subbase jalan setebal $50 \mathrm{~cm}$ sesuai dengan kondisi di lapangan yang dapat dilihat pada Gambar 9.

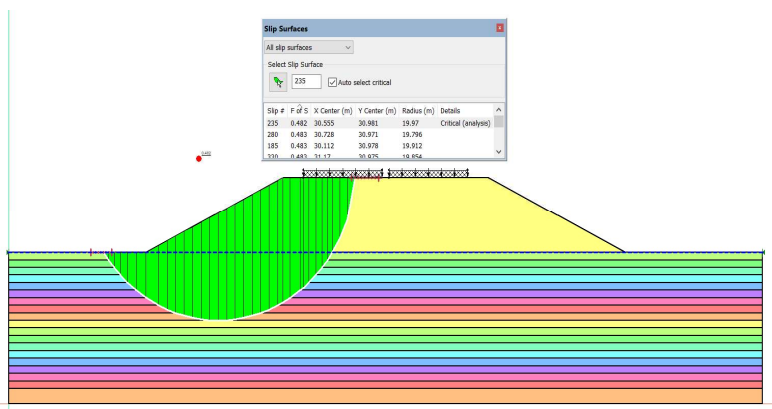

Gambar 7. Pemodelan pada program bantu GeoStudioSLOPE/W untuk kondisi tanpa dipasang PVD

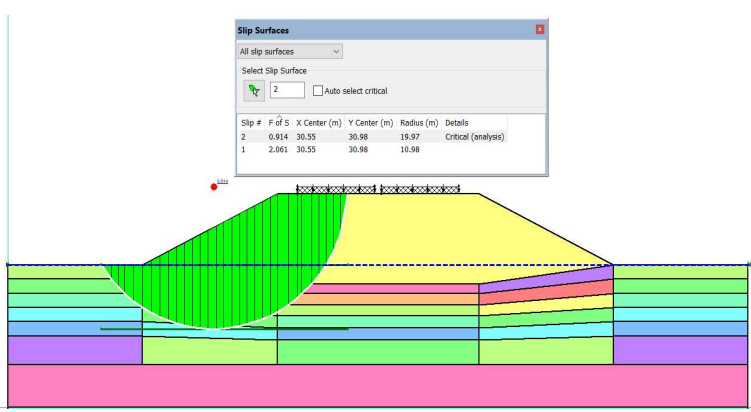

Gambar 8. Pemodelan pada program bantu GeoStudioSLOPE/W untuk kondisi dengan dipasang PVD

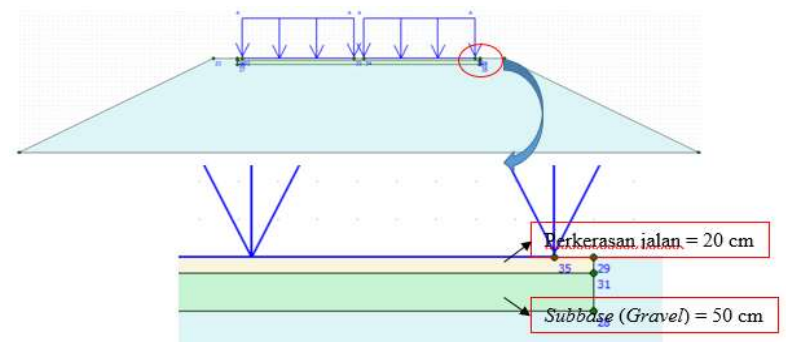

Gambar 9. Pemodelan perkerasan jalan dan subbase timbunan pada program bantu PLAXIS 
Pada program bantu PLAXIS perlu memasukkan parameter tanah modulus elastisitas (E) dan poisson ratio $(\mu)$. Pada penelitian ini, membuat data modifikasi nilai E dengan nilai $\mathrm{c}_{\mathrm{u}}$ untuk jenis tanah lempung. Rekapitulasi nilai E dan $\mathrm{c}_{\mathrm{u}}$ tanah lempung dapat dilihat pada Tabel 6 sehingga dapat disajikan ke dalam grafik yang dapat dilihat pada Gambar 10. Parameter tanah E didapatkan melalui persamaan yang dihasilkan dari grafik hubungan antara $c_{u}$ dengan $E$ untuk tanah lempung.

Tabel 6. Rekapitulasi Nilai $c_{u}$ [10] dan E [11]

\begin{tabular}{ccc}
$\begin{array}{c}\text { Konsistensi } \\
\text { Tanah }\end{array}$ & $\begin{array}{c}\mathbf{c u}_{\mathbf{u}} \\
\mathbf{k N} / \mathbf{m}^{\mathbf{2}}\end{array}$ & $\begin{array}{c}\mathbf{E} \\
\mathbf{k N} / \mathbf{m}^{\mathbf{2}}\end{array}$ \\
\hline \multirow{2}{*}{ Very Soft } & 0 & 300 \\
& 12 & 3000 \\
Soft & 13 & 2000 \\
& 24 & 4000 \\
Medium & 25 & 4500 \\
& 49 & 9000 \\
\hline
\end{tabular}

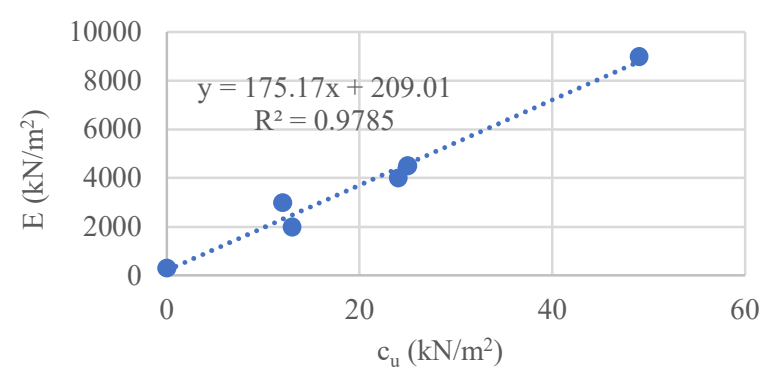

Gambar 10. Hubungan antara $c_{u}$ dengan E untuk tanah lempung

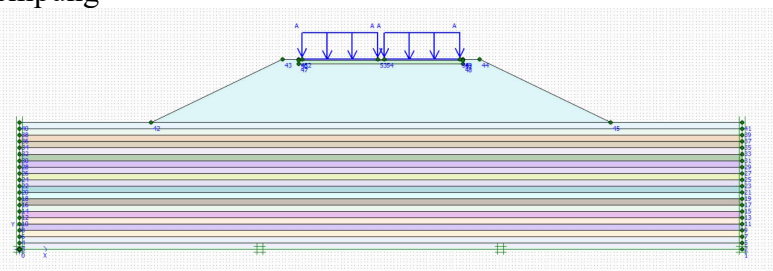

Gambar 11. Pemodelan pada program bantu PLAXIS untuk kondisi tanpa dipasang PVD

Nilai poisson ratio yang digunakan untuk jenis tanah lempung adalah 0.35 . Nilai modulus elastisitas untuk tanah pasir dense menggunakan $\mathrm{E}=50000 \mathrm{kN} / \mathrm{m}^{2}$ dan gravel dense menggunakan $\mathrm{E}=80000 \mathrm{kN} / \mathrm{m}^{2}$. Nilai poisson ratio jenis tanah pasir dan gravel yang digunakan sama seperti jenis tanah lempung, yaitu 0.35 [11].

Contoh pemodelan untuk kondisi tanpa dan dengan dipasang PVD dengan tinggi timbunan $10 \mathrm{~m}$ dan ketebalan tanah lunak 20 m dapat dilihat pada Gambar 11 dan Gambar
12. Sedang hasil bidang kelongsoran untuk kondisi tanpa dan dengan dipasang PVD dengan tinggi timbunan $10 \mathrm{~m}$ dan ketebalan tanah lunak $20 \mathrm{~m}$ dapat dilihat pada Gambar 13 dan Gambar 14.

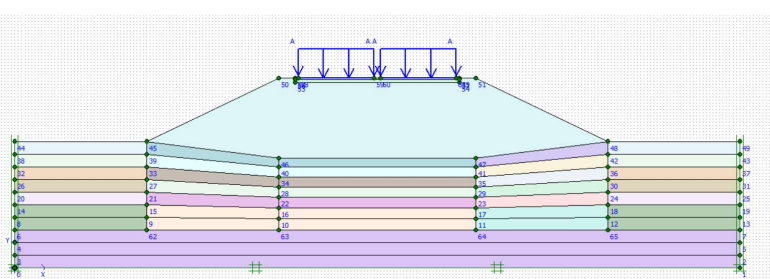

Gambar 12. Pemodelan pada program bantu PLAXIS untuk kondisi dengan dipasang PVD

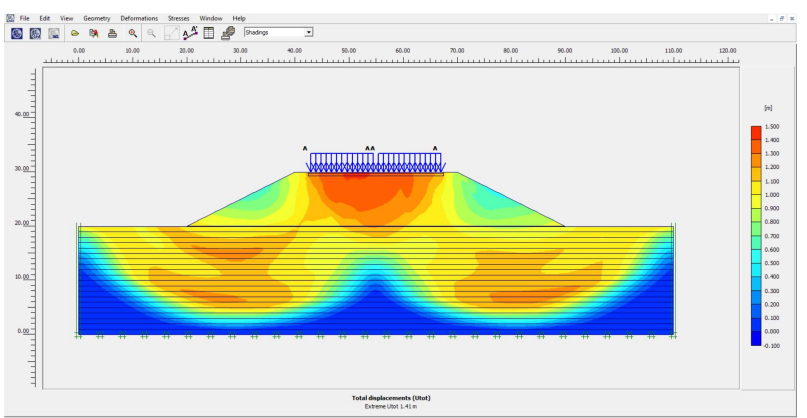

Gambar 13. Hasil bidang kelongsoran pada program bantu PLAXIS untuk kondisi tanpa dipasang PVD

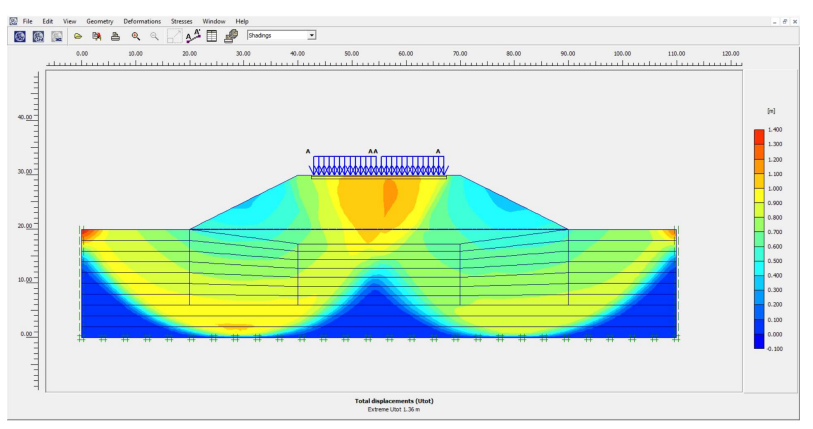

Gambar 14. Hasil bidang kelongsoran pada program bantu PLAXIS untuk kondisi dengan dipasang PVD

\section{Hasil Analisis Safety Factor dari Berbagai Program Bantu}

Setelah melakukan analisis stabilitas timbunan untuk kondisi inisial (lapisan tanah dasar tanpa dipasang PVD) dengan variasi ketinggian dan ketebalan tanah lunak maka akan diperoleh 1 nilai SF minimum dari masing-masing program bantu XSTABL, GEO5, GeoStudio-SLOPE/W, dan PLAXIS dari 5 iterasi yang telah dilakukan. Program bantu XSTABL memiliki keistimewaan dimana dapat menganalisis dengan memodelkan minimum seratus kemungkinan bidang longsor secara acak yang kemudian ditentukan sepu- 
luh SF minimum sehingga program bantu XSTABL dijadikan acuan dalam menganalisis perbandingan nilai SF minimum terhadap hasil dari program bantu GEO5, GeoStudioSLOPE/W, dan PLAXIS.

Dari hasil analisis stabilitas timbunan menggunakan program bantu XSTABL, GEO5, GeoStudio-SLOPE/W untuk kondisi tanpa dipasang PVD dari semua variasi ketinggian dan ketebalan tanah lunak, didapatkan bahwa dengan ketinggian $\mathrm{H}$ akan menghasilkan nilai SF minimum dan lingkaran bidang kelongsoran yang hampir sama untuk berbagai variasi ketebalan tanah lunak apabila ketebalan tanah lunak lebih besar dari tinggi timbunan $\mathrm{H}$.

Hasil perbandingan nilai SF minimum yang berupa koefisien pengali antara keempat program bantu untuk kondisi tanpa dan dengan dipasang PVD, dapat dilihat pada Tabel 7 dan Tabel 8.

Kesimpulan yang dapat ditarik dari Tabel 7 adalah untuk kondisi tanpa dipasang PVD dari semua variasi tinggi timbunan dan ketebalan tanah lunak, program bantu GEO5 dan GeoStudio-SLOPE/W menghasilkan nilai SF minimum lebih kecil daripada XSTABL tetapi nilai SF minimum yang dihasilkan oleh ketiga program bantu tersebut adalah hampir sama. Oleh karena itu dapat disimpulkan bahwa hasil program bantu GEO5 dan GeoStudio-SLOPE/W adalah reliable. Koefisien pengali nilai SF merupakan faktor koreksi yang dibutuhkan jika hasil nilai SF minimum pada program bantu GEO5 dan GeoStudio-SLOPE/W berbeda dari XSTABL. Sedang program bantu PLAXIS menghasilkan nilai SF minimum paling besar daripada XSTABL dan nilai SF minimum yang dihasilkan oleh program bantu PLAXIS berbeda dengan XSTABL. Oleh karena itu dapat disimpulkan bahwa hasil program bantu PLAXIS adalah tidak reliable. Koefisien pengali nilai SF merupakan faktor koreksi yang dibutuhkan oleh program bantu PLAXIS untuk menghasilkan nilai SF minimum yang sama dengan XSTABL.

Kesimpulan yang dapat ditarik dari Tabel 8 adalah untuk kondisi dengan dipasang PVD dari semua variasi tinggi timbunan dan ketebalan tanah lunak, program bantu GEO5 menghasilkan nilai SF minimum lebih kecil daripada XSTABL tetapi nilai SF minimum yang dihasilkan oleh kedua program bantu tersebut adalah hampir sama. Oleh karena itu dapat disimpulkan bahwa hasil program bantu GEO5 adalah reliable. Koefisien pengali nilai SF merupakan faktor koreksi yang dibutuhkan jika hasil nilai SF minimum pada program bantu GEO5 berbeda dari XSTABL. Program bantu GeoStudio-SLOPE/W menghasilkan nilai SF minimum lebih kecil daripada XSTABL dan nilai SF minimum yang dihasilkan oleh kedua program bantu tersebut adalah berbeda. Oleh karena itu dapat disimpulkan bahwa hasil program bantu GeoStudio-SLOPE/W adalah tidak reliable. Koefisien pengali nilai SF merupakan faktor koreksi yang dibutuhkan oleh program bantu GeoStudio-SLOPE/W untuk menghasilkan nilai SF minimum yang sama dengan XSTABL. Sedang program bantu PLAXIS menghasilkan nilai SF minimum lebih kecil daripada XSTABL dan nilai SF minimum yang dihasilkan oleh kedua program bantu tersebut adalah berbeda. Oleh karena itu dapat disimpulkan bahwa hasil program bantu PLAXIS adalah tidak reliable. Koefisien pengali nilai SF merupakan faktor koreksi yang dibutuhkan oleh program bantu PLAXIS untuk menghasilkan nilai SF minimum yang sama dengan XSTABL.

\section{Simpulan}

Dari hasil analisis dan pembahan dapat disimpulkan beberapa hal sebagai berikut:

1. Analisis stabilitas timbunan untuk semua variasi ketinggian yang diletakkan di atas tanah dasar dengan ketebalan tanah lunak yang bervariasi yang belum mengalami pemampatan (tanpa dipasang PVD) yang dilakukan dengan program bantu XSTABL, GEO5, dan GeoStudioSLOPE/W memberikan hasil angka keamanan (SF) yang sama; tetapi angka keamanan (SF) yang dihasilkan dari program bantu PLAXIS berbeda.

2. Analisis stabilitas timbunan untuk semua variasi ketinggian yang diletakkan di atas tanah dasar dengan ketebalan tanah lunak yang bervariasi yang telah mengalami pemampatan (dengan dipasang PVD) yang dilakukan dengan program bantu XSTABL dan GEO5 memberikan hasil angka keamanan (SF) yang sama; tetapi angka keamanan (SF) yang dihasilkan dari program bantu GeoStudio-SLOPE/W dan PLAXIS berbeda.

3. Penyebab perbedaan hasil angka keamanan (SF) yang diperoleh dari program bantu PLAXIS adalah proses kalkulasi untuk mencari nilai angka keamanan dengan menggunakan $\mathrm{phi} / \mathrm{c}$ reduction sedangkan pada program bantu XSTABL, GEO5, dan GeoStudio-SLOPE/W menggunakan metode irisan atau pias-pias dengan pendekatan bidang kelongsoran berbentuk circular. Sedang penyebab perbedaan hasil angka keamanan (SF) dari program bantu GeoStudio-SLOPE/W untuk kondisi tanah dasar sudah memampat (dengan dipasang PVD) adalah program bantu XSTABL dan GEO5 menghasilkan kedalaman bidang kelongsoran berbeda.

\section{Daftar Pustaka}

[1] D. J. G. Herman and G. T. Liong, “Analisa Stabilitas Lereng Limit Equilibrium dan Finite Element Method," HATTI-PIT-XVI, 2012. 
[2] M. Sungkar et al, "Slope stability analysis using Bishop and Finite Element Methods," in IOP Conference Series: Materials Science and Engineering, Banda Aceh, 2020.

[3] V. R. Desai and M. R. Joshi, "Slope Stability Evaluations by Limit Equilibrium and Finite Element Method," International Research Journal of Engineering and Technology, vol. VI, no. 09, pp. 756761, 2019.

[4] M. S. Sulaiman, A. H. Yusoff and N. D. Miniandi, "Slope Stability Evaluations Using Limit Equilibrium and Finite Element Methods," International Journal of Advanced Science and Technology, vol. XXVIII, no. 18, pp. 27-43, 2019.

[5] R. A. Septiandri, I. B. Mochtar and Y. Lastiasih, Metode Cepat untuk Menentukan Besar Pemampatan Konsolidasi (Sc) Timbunan di Atas Tanah Lunak dan Perencanaan Perkuatannya untuk Kondisi dengan dan Tanpa Pemasangan Prefabricated Vertical Drain (PVD), Thesis, Surabaya: Departemen Teknik Sipil Institut Teknologi Sepuluh Nopember, 2021.
[6] M. D. Ardana and I. B. Mochtar, Pengaruh Tegangan Overburden Efektif dan Plastisitas Tanah terhadap Kekuatan Geser Undrained Tanah Lempung Berkonsistensi Sangat Lunak Sampai Kaku yang Terkonsolidasi Normal, Thesis, Surabaya: Jurusan Teknik Sipil Institut Teknologi Sepuluh Nopember, 1999.

[7] A. Kosasih and I. B. Mochtar, Pengaruh Kadar Air, Angka Pori, dan Batas Cair Tanah Lempung Terhadap Indeks Pemampatan Konsolidasi Cc dan Indeks Pengembangan Cs, Thesis, Surabaya: Jurusan Teknik Sipil Institut Teknologi Sepuluh Nopember, 1997.

[8] N. E. Mochtar, Modul Ajar Metode Perbaikan Tanah, Surabaya: ITS Press, 2012.

[9] "SNI 8460-2017 Persyaratan Perancanagan Geoteknik," Badan Standarisasi Nasional, Jakarta, 2017.

[10] I. B. Mochtar, "Parameter Empiris untuk Tanah Lunak di Lapangan," Surabaya, 2001.

[11] J. E. Bowles, Sifat-Sifat Fisis dan Geoteknis Tanah (Mekanika Tanah), Jakarta: Erlangga, 1999.

Tabel 4. Data Tanah untuk Ketebalan Tanah Lunak 20 m [5]

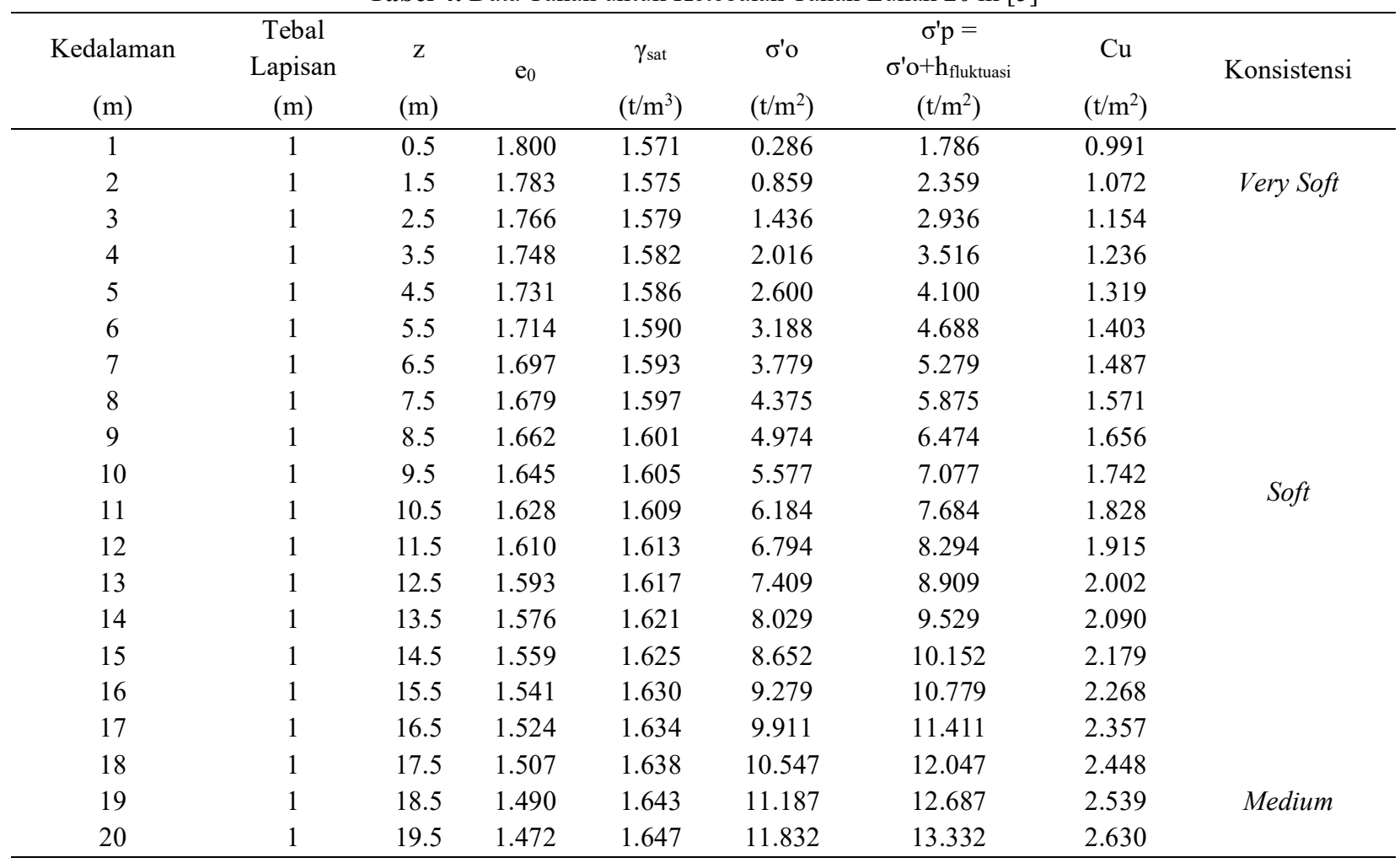


Tabel 7. Rekapitulasi Hasil Perbandingan Nilai SF Min. untuk Kondisi Tanpa Dipasang PVD

\begin{tabular}{|c|c|c|c|c|c|c|c|c|}
\hline $\begin{array}{c}\mathrm{H} \\
\text { Timbunan } \\
\end{array}$ & $\begin{array}{l}\text { Kedalaman } \\
\text { Tanah Dasar }\end{array}$ & \multicolumn{4}{|c|}{ SF Minimum } & \multicolumn{3}{|c|}{ Koefisien Pengali untuk SF } \\
\hline $\mathrm{m}$ & 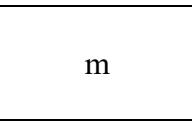 & XSTABL & GEO5 & $\begin{array}{l}\text { GeoStudio- } \\
\text { SLOPE/W }\end{array}$ & PLAXIS & $\begin{array}{c}\text { XSTABL / } \\
\text { GEO5 }\end{array}$ & $\begin{array}{l}\text { XSTABL / } \\
\text { GeoStudio- } \\
\text { SLOPE/W }\end{array}$ & $\begin{array}{l}\text { XSTABL } \\
\text { / PLAXIS }\end{array}$ \\
\hline \multirow{3}{*}{4} & 10 & 0.899 & 0.880 & 0.890 & 0.999 & 1.02 & 1.01 & 0.90 \\
\hline & 15 & 0.899 & 0.880 & 0.890 & 0.988 & 1.02 & 1.01 & 0.91 \\
\hline & 20 & 0.899 & 0.880 & 0.890 & 0.659 & 1.02 & 1.01 & 1.36 \\
\hline \multirow{3}{*}{6} & 10 & 0.678 & 0.670 & 0.669 & 0.760 & 1.01 & 1.01 & 0.89 \\
\hline & 15 & 0.678 & 0.660 & 0.674 & 0.790 & 1.03 & 1.01 & 0.86 \\
\hline & 20 & 0.678 & 0.660 & 0.669 & 0.722 & 1.03 & 1.01 & 0.94 \\
\hline \multirow{3}{*}{8} & 10 & 0.565 & 0.550 & 0.558 & 0.645 & 1.03 & 1.01 & 0.88 \\
\hline & 15 & 0.565 & 0.550 & 0.558 & 0.663 & 1.03 & 1.01 & 0.85 \\
\hline & 20 & 0.565 & 0.550 & 0.558 & 0.654 & 1.03 & 1.01 & 0.86 \\
\hline \multirow{3}{*}{10} & 10 & 0.493 & 0.480 & 0.482 & 0.561 & 1.03 & 1.02 & 0.88 \\
\hline & 15 & 0.493 & 0.490 & 0.482 & 0.556 & 1.01 & 1.02 & 0.89 \\
\hline & 20 & 0.493 & 0.490 & 0.482 & 0.565 & 1.01 & 1.02 & 0.87 \\
\hline
\end{tabular}

Tabel 8. Rekapitulasi Hasil Perbandingan Nilai SF Min. untuk Kondisi dengan Dipasang PVD

\begin{tabular}{|c|c|c|c|c|c|c|c|c|}
\hline $\begin{array}{c}\mathrm{H} \\
\text { Timbunan }\end{array}$ & $\begin{array}{l}\text { Kedalaman } \\
\text { Tanah Dasar }\end{array}$ & \multicolumn{4}{|c|}{ SF Minimum } & \multicolumn{3}{|c|}{ Koefisien Pengali untuk SF } \\
\hline $\mathrm{m}$ & $\mathrm{m}$ & XSTABL & GEO5 & $\begin{array}{l}\text { GeoStudio- } \\
\text { SLOPE/W }\end{array}$ & PLAXIS & $\begin{array}{l}\text { XSTABL } \\
\text { / GEO5 }\end{array}$ & $\begin{array}{l}\text { XSTABL / } \\
\text { GeoStudio- } \\
\text { SLOPE/W }\end{array}$ & $\begin{array}{l}\text { XSTABL } \\
\text { / PLAXIS }\end{array}$ \\
\hline \multirow{3}{*}{4} & 10 & 1.096 & 1.080 & 1.025 & 0.821 & 1.01 & 1.07 & 1.34 \\
\hline & 15 & 1.113 & 1.100 & 1.054 & 0.787 & 1.01 & 1.06 & 1.41 \\
\hline & 20 & 1.124 & 1.130 & 1.050 & 1.136 & 0.99 & 1.07 & 0.99 \\
\hline \multirow{3}{*}{6} & 10 & 0.933 & 0.960 & 0.963 & 0.946 & 0.97 & 0.97 & 0.99 \\
\hline & 15 & 0.945 & 1.000 & 0.880 & 0.961 & 0.95 & 1.07 & 0.98 \\
\hline & 20 & 1.024 & 1.020 & 1.019 & 1.004 & 1.00 & 1.00 & 1.02 \\
\hline \multirow{3}{*}{8} & 10 & 0.911 & 0.900 & 0.901 & 0.925 & 1.01 & 1.01 & 0.98 \\
\hline & 15 & 0.937 & 0.910 & 0.803 & 0.874 & 1.03 & 1.17 & 1.07 \\
\hline & 20 & 0.961 & 0.950 & 0.832 & 0.862 & 1.01 & 1.16 & 1.11 \\
\hline \multirow{3}{*}{10} & 10 & 0.860 & 0.850 & 0.857 & 0.884 & 1.01 & 1.00 & 0.97 \\
\hline & 15 & 0.894 & 0.860 & 0.756 & 0.893 & 1.04 & 1.18 & 1.00 \\
\hline & 20 & 0.919 & 0.900 & 0.828 & 0.783 & 1.02 & 1.11 & 1.17 \\
\hline
\end{tabular}

